\title{
ENERGY REGENERATION IN AUTOMATED HIGH BAY WAREHOUSE WITH STACKER CRANES
}

\author{
Boris Jerman, Nenad Zrnić, Matjaž Jenko, Tone Lerher
}

Original scientific paper

Fully automated electrically powered stacker cranes are the most common transportation devices used in automated high bay warehouses. When high throughputs are attained, the amount of the electric energy used is high. Taking this into account, together with relatively high rack configuration the energy saving by employing the regeneration of potential energy during the lowering of the stored goods seems to be a promising choice. In the paper real life data for deployment of four stacker cranes in high bay warehouse of bigger dairy is introduced and analysed. The cranes' working cycles are determined and their energy consumption is estimated. Finally, the probable energy and costs savings are determined taking into account the regenerated energy for crane operations and lower energy consumption for refrigeration purposes.

Keywords: energy consumption; energy regeneration; high bay warehouses; stacker crane

Regeneracija energije u automatiziranom visokoregalnom skladištu s regalnim dizalicama

Izvorni znanstveni članak

Najčešći transportni uređaji koji se koriste u automatiziranim visokoregalnim skladištima su električne regalne dizalice. Kod dostizanja visokih pretovarnih kapaciteta dolazi do velike potrošnje električne energije. Uzimajući ovo u obzir, a imajući u vidu i relativno visoke regale, regeneracija potencijalne energije tijekom spuštanja uskladištene robe može biti dobro rješenje za uštedu energije. Za analize u radu su upotrebljeni realni podaci vezani za radne operacije četiri dizalice u visokoregalnom skladištu velike mljekare. Određeni su radni ciklusi dizalica i procjenjena je njihova potrošnja energije. Konačno, određene su vjerojatne uštede energije i troškova, uzimajući u obzir regeneriranu energiju i smanjeni utrošak energije za hlađenje skladišta.

Ključne riječi: potrošnja energije; regalne dizalice; regeneracija energije; regalna skladišta

\section{Introduction}

Automated high bay warehouses are one of the most popular choices for many types of warehousing purposes. They are typically high-rise storage units with a relatively small ground plan, using traditional Crane-Based Automated Storage and Retrieval System (CBAS/RS), which usually consist of conveyors, racks and automated Storage/Retrieval (S/R) machines (crane) [1]. In recent time instead of CBAS/RS also Autonomous Vehicle Storage and Retrieval Systems (AVS/RS) which is a relatively new technology for automated Unit-Load warehouses, has been implemented, mostly in Europe [2]. Primarily for mini-load warehouses a Shuttle Based Storage and Retrieval System (SBS/RS) was developed, which is a branch of AVS/RS technology [3, 4].

Performance evaluation and comparison of AVS/RS and CBAS/RS material handling systems of automated high bay warehouses is an actual research theme. AVS/RS was first studied by Malmborg $[2,5]$. Kuo et al. $[6,7]$ developed a computationally efficient cycle time model for AVS/RS for estimation of resource utilization. Zhang et al. [8] studied variance based approximation for AVS/RS waiting times. Ekren et al. [9, 10, 11] evaluated performance of AVS/RS by means of simulation. Lerher et al. [12] studied multi-objective optimization for automated warehouses. Recently, Lerher [13] and Lerher et al. [4] studied energy regeneration and energy efficiency models for SBS/RS. The comparison of effectiveness of CBAS/RS and AVS/RS was studied by Sunderesh et al. [14] and Ekren et al. [15]. Flynn et al. [16] studied energy recovery and emission cutting in mobile gantry cranes. Wang et al. [17] studied the key aspects of energy waste of portal cranes and compared energy storage technologies to get the most suitable technology for crane energy regeneration. The flywheel energy regeneration system was chosen and energy efficiency was calculated based on data measured in a port. Liu Haiwei et al. [18] developed and verified a simulation platform of a real-life portal crane intended for portal crane energy saving researches.

In the present work the energy consumption of real life stacker cranes' operations and the possibilities regarding the electric power regeneration during descending of the stored goods are studied. The enlarging of savings due to the operation of the cranes in a cooled dairy warehouse is also introduced.

\section{Automated high bay warehouse \\ 2.1 The warehouse technical data}

The studied automated high bay warehouse appertains to bigger dairy. For the purpose of storage of dairy products the warehouse is cooled to $5^{\circ} \mathrm{C}$. It consists of 4 aisles with racks on both sides (Fig. 1). There is one stacker crane (Fig. 2) per each aisle.

The load, which must be stored (the tote), is located on a cargo pallet (Fig. 4) and transferred to the corresponding stacker crane by means of an automated conveyor. The crane takes over the cargo and transports it to an empty location in the rack. Retrieval of the load goes in the opposite order of operations. Storage and retrieval operations are fully automatized and the material flow is controlled by a computer program.

The warehouse's approximate dimensions are $60 \times 25$ $\times 20 \mathrm{~m}$ (length $\times$ width $\times$ height) as shown in Fig. 1. It has 4 aisles. Each of them has a single or a double rack on every side (together 13 single racks (Fig. 3)). There are 11 tiers (rows) and 61 columns in each rack. The warehouse has around 8700 storage positions in the racks $(13 \times 61 \times$ $11=8723)$. 


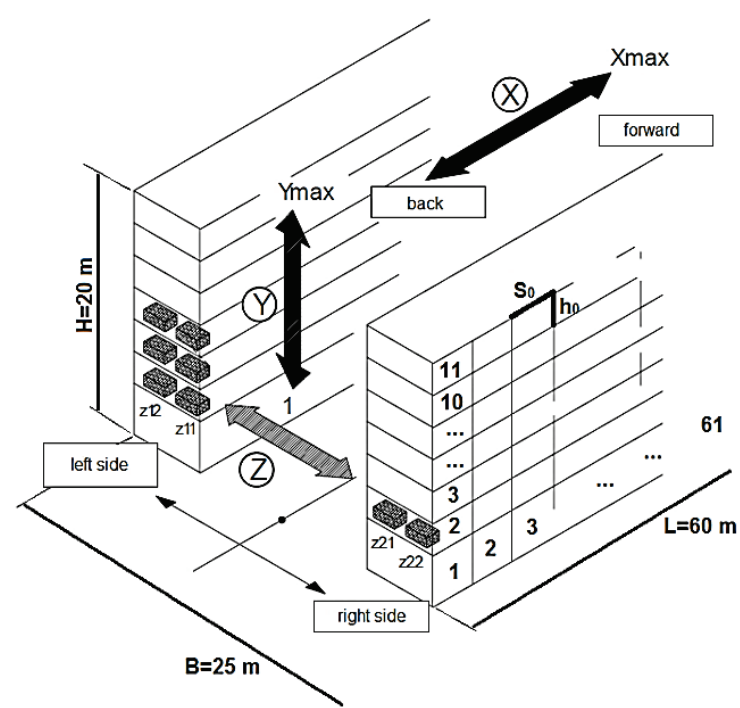

Figure 1Warehouse aisle with coordinate systems (Scheme is from Instructions for use, SchäferNoell, RGB_Ba_3_0.2006.)

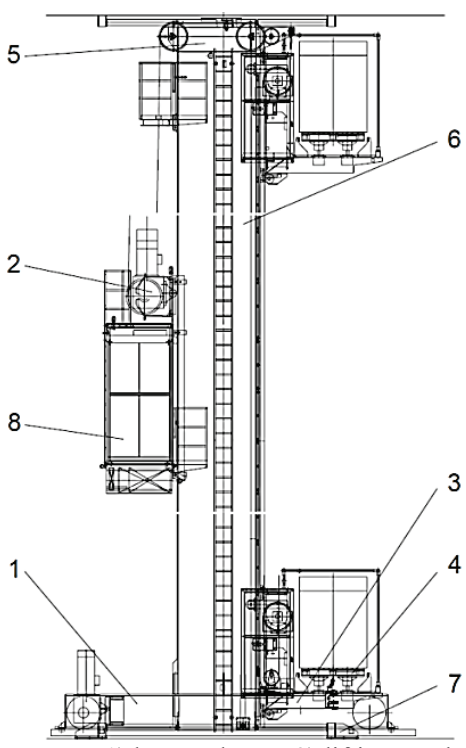

Figure 2 Stacker crane: 1) bottom beam, 2) lifting mechanism, 3) lifting platform, 4) extracting device, 5) top beam, 6) column with equipment, 7) aisle equipment, 8) electric cabinet. (Scheme is from Instructions for use, SchäferNoell, RGB_Ba_3_0.2006.)

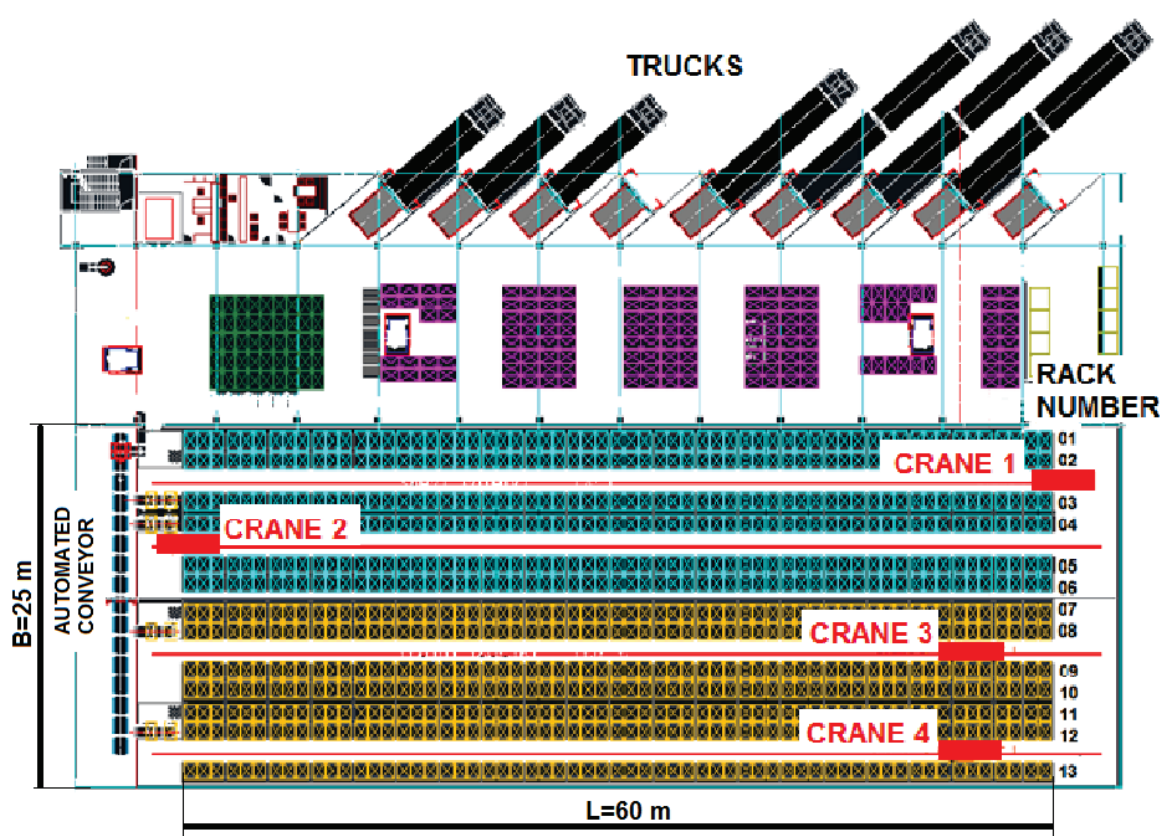

Figure 3 Layout of the warehouse with 13 racks [19]

As a system pallet the Euro-like pallet of dimensions $1200 \times 800 \times 144 \mathrm{~mm}$ is used. The maximal load dimensions (including the pallet) are $1350 \times 900 \times 1500$ mm (Fig. 4).

The accelerations and velocities of crane movements are introduced in Tab. 1. The stacker crane is intended to be used for 24 hours 6 days per week. The crane capacity is $m_{Q, \max }=950 \mathrm{~kg}$. The mass of the lifting platform (and other lifted crane components) is $m_{\mathrm{p}}=740 \mathrm{~kg}$. The mass of the crane without the lifting platform is $m_{\mathrm{c}}=6200 \mathrm{~kg}$.
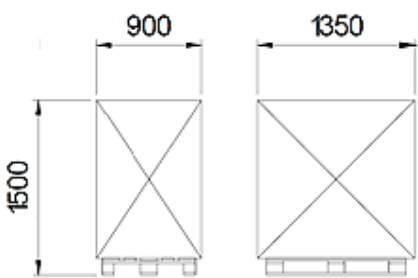

Euro Pallet $800 \times 1200$

Figure 4 System pallet with the load (dimensions) (Scheme is from Instructions for use, SchäferNoell, RGB_Ba_3_0.2006.)

Table 1 Accelerations, decelerations and velocities of stacker crane movements

\begin{tabular}{|c|c|c|c|}
\hline & Crane travelling & Platform lifting & Pallet extraction \\
\hline Velocity & $v_{\mathrm{s}}=135 \mathrm{~m} / \mathrm{min}$ & $\begin{array}{c}v_{\mathrm{h}}=5 \mathrm{~m} / \mathrm{min}(\mathrm{normal}) \\
2 \mathrm{~m} / \mathrm{min} \text { (positioning) }\end{array}$ & $\begin{array}{c}v_{\mathrm{p}}=73 \mathrm{~m} / \mathrm{min} \text { (empty pallet) } \\
42 \mathrm{~m} / \mathrm{min} \text { (fully loaded pallet) }\end{array}$ \\
\hline Acceleration/deceleration & $a_{\mathrm{s}}=0,5 \mathrm{~m} / \mathrm{s}^{2}$ & $a_{\mathrm{h}}=0,6 \mathrm{~m} / \mathrm{s}^{2}$ & $\begin{array}{c}a_{\mathrm{p}}=2,0 \mathrm{~m} / \mathrm{s}^{2} \text { (empty pallet) } \\
0,6 \mathrm{~m} / \mathrm{s}^{2} \text { (fully loaded pallet) }\end{array}$ \\
\hline
\end{tabular}




\subsection{Deployment of stacker cranes}

In this chapter the data of the real life deployment of all four stacker cranes in the high bay warehouse is introduced. The data for the period of 38 consecutive days is available. The structure of the data and data samples are shown in Tab. 2.

The following data of movements of separate loads (tote) is available:

- identification numbers of the crane operation and of the load;

- position of the source storage location in the rack or on the entering/retrieval location of the individual aisle;

- position of the destination storage location in the rack or the entering/retrieval location of individual aisle;

- overall distances of the movements of the load (calculated);

- operation starting time;
- operation ending time;

- time elapsed during allocation of the load (calculated);

- accelerations, decelerations and maximal velocities of crane movements.

There are 63820 records of loaded crane movements available and further 63820 movements of the empty crane are assumed for connection of the documented crane operations. The analysis of the efficiency of the retraction of the stored goods' (totes') potential energy is conducted and the retracted energy is compared with overall electric energy consumed by crane operations. Therefore the height of goods in last few data records of crane movements was adjusted in such a manner that the overall path travelled during lifting of the loaded crane equals to the overall path travelled during lowering of the loaded crane. By that a fair comparison was enabled.

Table 2 Available data of stacker cranes deployment (sample)

\begin{tabular}{|c|c|c|c|c|c|c|c|c|c|c|}
\hline Day & 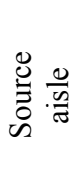 & 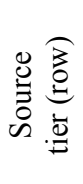 & 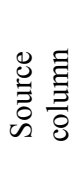 & 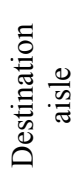 & 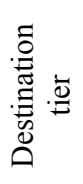 & 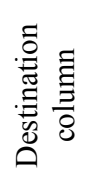 & $\begin{array}{l}\text { Time } \\
\text { started }\end{array}$ & $\begin{array}{l}\text { Time } \\
\text { finished }\end{array}$ & 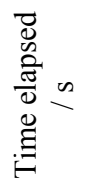 & $\begin{array}{c}\text { Crane } \\
\text { deployed }\end{array}$ \\
\hline 1 & 3 & 7 & 1 & $0 *$ & $0 *$ & $0 *$ & $\begin{array}{l}\text { sep 02, } 20^{* *} \\
\text { 04:09:42 PM }\end{array}$ & $\begin{array}{l}\text { sep 02, 20** } \\
04: 10: 06 \text { PM }\end{array}$ & 24 & 3 \\
\hline 1 & $0^{*}$ & $0^{*}$ & $0^{*}$ & 3 & 9 & 10 & $\begin{array}{l}\text { sep 02, } 20^{* *} \\
04: 09: 45 \text { PM }\end{array}$ & $\begin{array}{l}\text { sep 02, 20** } \\
04: 10: 35 \text { PM }\end{array}$ & 50 & 3 \\
\hline 1 & 3 & 7 & 1 & $0^{*}$ & $0^{*}$ & $0 *$ & $\begin{array}{c}\text { sep } 02,20^{* *} \\
04: 11: 15 \text { PM }\end{array}$ & $\begin{array}{l}\text { sep } 02,20^{* *} \\
04: 11: 39 \text { PM }\end{array}$ & 24 & 3 \\
\hline$\ldots$ & $\ldots$ & $\ldots$ & $\ldots$ & $\ldots$ & $\ldots$ & $\ldots$ & $\ldots$ & $\ldots$ & $\ldots$ & $\ldots$ \\
\hline 2 & 1 & 5 & 5 & $0^{*}$ & $0^{*}$ & $0^{*}$ & $\begin{array}{l}\text { sep } 03,20^{* *} \\
12: 02: 59 \text { AM }\end{array}$ & $\begin{array}{l}\text { sep 03, } 20^{* *} \\
\text { 12:03:20 AM }\end{array}$ & 21 & 1 \\
\hline 2 & 0 & 0 & 0 & 1 & 2 & 35 & $\begin{array}{c}\text { sep 03, 20** } \\
\text { 12:03:01 AM }\end{array}$ & $\begin{array}{c}\text { sep 03, 20** } \\
\text { 12:03:57 AM }\end{array}$ & 56 & 1 \\
\hline 2 & 2 & 7 & 20 & $0^{*}$ & $0 *$ & $0^{*}$ & $\begin{array}{c}\text { sep 03, 20** } \\
\text { 12:03:09 AM }\end{array}$ & $\begin{array}{l}\text { sep 03, } 20^{* *} \\
\text { 12:03:44 AM }\end{array}$ & 35 & 2 \\
\hline$\ldots$ & $\ldots$ & $\ldots$ & $\ldots$ & $\ldots$ & $\ldots$ & $\ldots$ & $\ldots$ & $\ldots$ & $\ldots$ & $\ldots$ \\
\hline 38 & 3 & 4 & 19 & $0 *$ & $0^{*}$ & $0^{*}$ & $\begin{array}{c}\text { oct } 08,20^{* *} \\
12: 00: 04 \mathrm{AM}\end{array}$ & $\begin{array}{l}\text { okt } 08,20^{* *} \\
12: 00: 44 \mathrm{AM}\end{array}$ & 40 & 1 \\
\hline 38 & $0^{*}$ & $0^{*}$ & $0^{*}$ & 3 & 5 & 1 & $\begin{array}{c}\text { oct } 08,20^{* *} \\
12: 00: 05 \text { PM }\end{array}$ & $\begin{array}{c}\text { okt } 08,20^{* *} \\
12: 01: 13 \text { AM }\end{array}$ & 68 & 1 \\
\hline 38 & 1 & 3 & 47 & 0 * & $0^{*}$ & $0^{*}$ & $\begin{array}{c}\text { oct } 08,20^{* *} \\
12: 01: 24 \text { AM }\end{array}$ & $\begin{array}{c}\text { okt } 08,20^{* *} \\
12: 02: 02 \mathrm{AM}\end{array}$ & 38 & 1 \\
\hline
\end{tabular}

*... When source or destination aisle, tier and column are numbered as 0 , the corresponding source or destination location is entering/retrieval location of the individual aisle.

**... The year of the cranes movements is hidden on purpose.

\section{Analysis procedure \\ 3.1 Assumptions}

The following assumptions are adopted:

1) after completion of the task the crane keeps its position in the aisle, waiting for another task;

2) during the analyses always the average mass of the transported payload $m_{Q}$ is taken into account when the loaded crane movements are analysed (estimated as $75 \%$ of the crane maximal load capacity $m_{Q, \max }$ );

3 ) the total (electric and mechanical) efficiency of the driving gear-motor-reducers is $\eta_{\mathrm{s}}=70,4 \%$;

4) the total (electric and mechanical) efficiency of the lifting gear-motor-reducers is $\eta_{\mathrm{h}}=62,8 \%$;
5) the friction torque lever arm for steel wheels on the steel rail: $f_{\mathrm{s}}=0,5 \mathrm{~mm}$;

6) the friction torque lever arm for polymer wheels on the steel guide: $f_{\mathrm{h}}=1,0 \mathrm{~mm}$;

7) the diameter of the crane travelling wheels $d_{\mathrm{s}}=$ $300 \mathrm{~mm}$;

8) the diameter of the polymer guiding wheels $d_{\mathrm{h}}=$ $150 \mathrm{~mm}$;

9) the efficiency of the regenerative process of transformation of the potential energy into electric energy and its retrieval into the mains $\eta_{\mathrm{RP}}=70 \%$;

10) the overall efficiency of the warehouse cooling process $\eta_{\mathrm{CP}}=70 \%$; 
11) during the controlled decreasing of the crane traveling velocity no electric energy is consumed by the motor;

12) during the controlled descending of the crane platform and during its acceleration and deceleration during descending no electric energy is consumed by the motor.

\subsection{Equations}

The energy consumption of the crane driving mechanism is calculated as a sum of the following contributions (Eqs. (1) and (4)).

The work, needed to accelerate the crane to individual maximum travelling velocity $v_{\mathrm{s}, \max }$ is:

$E_{\mathrm{k}, \mathrm{s}}=\left(m_{\mathrm{c}}+m_{\mathrm{p}}+m_{Q}\right) \cdot \frac{v_{\mathrm{s}, \max }^{2}}{2} \cdot \frac{1}{\eta_{\mathrm{s}}}$,

where the individual maximal travelling velocity is:

$v_{\mathrm{s}, \max }=v_{\mathrm{s}}$,

if the individual travelling distance $s_{\mathrm{i}}$ is long enough that the nominal travelling velocity $v_{\mathrm{s}}$ can be achieved or:

$v_{\mathrm{s}, \max }=\sqrt{a_{\mathrm{s}} \cdot s_{\mathrm{i}}}$

in case that the travelling distance is too small.

The work for overcoming the rolling friction of the crane wheels rolling on the rails is determined as:

$A_{\mathrm{s}}=\frac{2 g \cdot\left(m_{\mathrm{c}}+m_{\mathrm{p}}+m_{Q}\right) \cdot f_{\mathrm{s}} \cdot s}{d_{\mathrm{s}} \cdot \eta_{\mathrm{s}}}$,

where $g$ is the gravity acceleration and $\eta_{\mathrm{s}}$ is the efficiency of the crane driving mechanism. It is assumed that further $20 \%$ of that work is needed for overcoming the dissipation of energy by the crane upper guiding wheels.

The energy consumption of the crane lifting mechanism during the lifting action is calculated as a sum of the following contributions (see (5), (8) and (9)).

The work, needed to accelerate the crane lifting platform with the load to individual maximum travelling velocity $v_{\mathrm{h}, \max }$ is:

$E_{\mathrm{k}, \mathrm{h}}=\frac{\left(m_{\mathrm{p}}+m_{Q}\right) \cdot v_{\mathrm{h}, \max }^{2}}{2 \eta_{\mathrm{h}}}$,

where the individual maximal travelling speed is:

$v_{\mathrm{h}, \max }=v_{\mathrm{h}}$,

if the individual lifting distance $h_{\mathrm{i}}$ is long enough that the nominal travelling speed $v_{\mathrm{h}}$ can be achieved or:

$v_{\mathrm{h}, \max }=\sqrt{a_{\mathrm{h}} \cdot h_{\mathrm{i}}}$, in case that the lifting distance is too small.

The work for overcoming the rolling friction of rolling of the guiding wheels on the vertical guide is determined as:

$A_{\mathrm{h}}=\frac{1}{10} \cdot \frac{2 g \cdot\left(m_{\mathrm{p}}+m_{Q}\right) \cdot f_{\mathrm{h}} \cdot h_{\mathrm{i}}}{d_{\mathrm{h}} \cdot \eta_{\mathrm{h}}}$

where $1 / 10$ represents an assumption that about $10 \%$ of the mass contributes to the normal force on the vertical guides, which acts in the horizontal direction and generates the rolling friction force.

When vertical motion is analysed also the potential energy must be regarded:

$E_{\mathrm{p}, \mathrm{h}}=\frac{g \cdot\left(m_{\mathrm{p}}+m_{Q}\right) \cdot h_{\mathrm{i}}}{\eta_{\mathrm{h}}}$.

For the regeneration of the energy only potential energy of the lifted masses is appropriate. The regenerated electric energy is smaller than the available potential energy for the efficiency of the transformation process:

$E_{\text {el. reg }}=g \cdot\left(m_{\mathrm{p}}+m_{Q}\right) \cdot h_{\mathrm{i}} \cdot \eta_{\mathrm{RP}}$.

\subsection{The computer program}

The introduced data (Tabs. 1 and 2, assumptions) and equations ((1) to (10)) were used for analysis, which was performed in Excel software.

\begin{tabular}{|l|c|c|c|}
\hline \multicolumn{1}{|c|}{ Crane status: } & Loaded & Empty & MJ \\
\hline Movement: & & & Sum \\
\hline Crane travelling & 1298 & 859 & 2157 \\
\hline$E_{\mathrm{k}, \mathrm{s}}$ & 928 & 646 & \\
\hline $1.2 A_{\mathrm{s}}$ & 370 & 213 & \\
\hline Platform lifting & 6927 & 1335 & 8262 \\
\hline$E_{\mathrm{k}, \mathrm{h}}$ & 109 & 49 & \\
\hline$A_{\mathrm{h}}$ & 6758 & 1266 & \\
\hline$E_{\mathrm{p}, \mathrm{h}}$ (lifting) & 4243 & 795 & 5038 \\
\hline Platform lowering & 4243 & 795 & \\
\hline$E_{\mathrm{p}, \mathrm{h}}$ (lowering) & & & 10419 \\
\hline $\begin{array}{l}\text { Sum of the energy used for } \\
\text { accelerations, movements and } \\
\text { lifting } E_{\mathrm{cr}}\end{array}$ & & & 5038 \\
\hline $\begin{array}{l}\text { Sum of the energy available for } \\
\text { the regeneration } E_{\mathrm{av}}\end{array}$ & & & 3526 \\
\hline $\begin{array}{l}\text { Regenerated electric energy taking } \\
\text { into account the efficiency of the } \\
\text { regeneration process } \eta_{\mathrm{RP}} E_{\mathrm{reg}}\end{array}$ & & & \\
\hline
\end{tabular}

\subsection{Possible energy savings in 38 days}

If the regenerated electric energy is compared to the electric energy used by crane operations:

$\delta_{\text {el. reg }}=\frac{E_{\text {reg }}}{E_{\text {cr }}}=\frac{3526}{10419}=0,338$,

it is clear that around $34 \%$ of the electric energy used could be regenerated. 
Furthermore the fact that the dissipated electric energy is transformed into the thermal energy which is heating the cold warehouse can be taken into account. In order to preserve low temperature, additional electric energy is used in the cooling system. The regenerated electric energy which is not transferred into the heat therefore saves a portion of the cooling energy. Its amount is, due to the efficiency of the cooling process, higher than the regenerated crane electric energy:

$E_{\mathrm{cool}}=\frac{E_{\mathrm{reg}}}{\eta_{\mathrm{CP}}}=\frac{3526}{0,7}=5038 \mathrm{MJ}$

The total energy saved in case of implementation of the regeneration process would therefore be:

$$
E_{\mathrm{tot}}=E_{\mathrm{reg}}+E_{\mathrm{cool}}=3526+5038=8564 \mathrm{MJ} .
$$

If the possible total electric energy saved is compared to the electric energy used by crane operations:

$\delta_{\text {tot }}=\frac{E_{\text {tot }}}{E_{\text {cr }}}=\frac{8564}{10419}=0,822$,

it is clear that the total energy, which can be saved by implementation of the regeneration process in this particular case with cooled warehouse is around $82 \%$ of the electric energy used solely by the crane operations.

\subsection{Potential annual savings}

Using the calculated energies as references, the information that warehouse operates approximately 313 days per year and the appropriate electric energy price $0.12 € /(\mathrm{kW} \cdot \mathrm{h})$, the savings introduced in Tab. 4 can be estimated.

Table 4 Potential annual savings of the electric energy in $\mathrm{MJ}, \mathrm{kW} \cdot \mathrm{h}$ and $€$

\begin{tabular}{|l|c|c|c|}
\hline & $\mathrm{MJ}$ & $\mathrm{kW} \cdot \mathrm{h}$ & $€$ \\
\hline $\begin{array}{l}\text { Annually regenerated electric } \\
\text { energy }\end{array}$ & 29046 & 8068 & 968 \\
\hline $\begin{array}{l}\text { Overall annually saved electric } \\
\text { energy }\end{array}$ & 70540 & 19595 & 2351 \\
\hline
\end{tabular}

Beside the fair annual economic savings, the environmental impact is reduced proportionally.

\section{Conclusion}

In the paper, data of the real word high bay warehouse are introduced. The warehouse and racks' dimensions are given among cranes' capacity, crane movements' velocities and accelerations and crane deployment data.

Raw data from the warehouse controlling software are prepared in a way which enables further studies. The data introduced was used for determination of the energy consumption of the existing warehouse. The regeneration of the potential energy of the stored goods by its transformation into electric energy is proposed and fair possible energy and costs savings are established. It is shown that, by doing so, more than one third of the energy used for the crane operations can be restored. Furthermore it is encountered that, when the costs of the warehouse refrigeration are also taken into account, the energy savings are around $82 \%$ of the energy used by cranes. In that case the estimated annual costs savings would be around $2350 €$. The ecological aspects of the warehouse operations are also improved.

\section{References}

[1] Van den Berg, J. P.; Zijm, W. H. M. Models for warehouse management: Classification and examples. // International Journal of Production Economics. 59, (1999), pp. 519-528. https://doi.org/10.1016/S0925-5273(98)00114-5

[2] Malmborg, C. J. Conceptualizing tools for autonomous vehicle storage and retrieval systems. // International Journal of Production Research. 40, 8(2002), pp. 18071822. https://doi.org/10.1080/00207540110118668

[3] Carlo, H. J.; Vis, I. F. A. Sequencing dynamic storage systems with multiple lifts and shuttles. // International Journal of Production Economics. 140, (2012), pp. 844853. https://doi.org/10.1016/j.jpe.2012.06.035

[4] Lerher, T.; Edl, M.; Rosi, B. Energy efficiency model for the mini-load automated storage and retrieval systems. // International Journal of Advanced Manufacturing Technology. 70, (2013), pp. 97-115. https://doi.org/10.1007/s00170-013-5253-x

[5] Malmborg, C. J. Interleaving rule dynamics in autonomous vehicle storage and retrieval systems. // International Journal of Production Research. 41, 5(2003), pp. 10571069. https://doi.org/10.1080/0020754021000033887

[6] Kuo, P. H.; Krishnamurthy, A.; Malmborg, C. J. Design models for unit load storage and retrieval systems using autonomous vehicle technology and resource conserving storage and dwell point policies. // Applied Mathematical Modelling. 31, 10(2007), pp. 2332-2346. https://doi.org/10.1016/j.apm.2006.09.011

[7] Kuo, P. H.; Krishnamurthy, A.; Malmborg, C. J. Performance modelling of autonomous vehicle storage and retrieval systems using class-based storage policies. // International Journal of Computer Applications in Technology. 31, 4(2008), pp. 238-248. https://doi.org/10.1504//JCAT.2008.018160

[8] Zhang, L.; Krishnamurthy, A.; Malmborg, C. J.; Heragu, S. S. Variance-based approximations of transaction waiting times in autonomous vehicle storage and retrieval systems. // European Journal of Industrial Engineering. 3, 2(2009), pp. 146-168. https://doi.org/10.1504/EJIE.2009.023603

[9] Ekren, B. Y.; Heragu, S. S.; Krishnamurthy, A.; Malmborg, C. J. Simulation based experimental design to identify factors affecting performance of AVS/RS. // Computers \& Industrial Engineering. 58, (2010), pp. 175-185. https://doi.org/10.1016/j.cie.2009.10.004

[10] Ekren, B. Y. Performance evaluation AVS/RS under various design scenarios: a case study. // International Journal of Advanced Manufacturing Technology. 55, (2011), pp. 1253-1261. https://doi.org/10.1007/s00170-010-3137-x

[11] Ekren, B. Y.; Heragu, S. S. Simulation based performance analysis of an autonomous vehicle storage and retrieval system. // Simulation Modelling Practice and Theory. 19, (2011), pp. 1640-1650. https://doi.org/10.1016/j.simpat.2011.02.008

[12] A multi objective model for optimization of automated warehouses. // Logistics: perspectives, approaches and challenges/Lerher, T.; Borovinšek, M.; Šraml, M. New York: Nova Publishers, 2013.pp. 87-110. 
[13] Modern automation in warehousing by using the shuttle based technology. // Automation Systems of the 21st Century: New Technologies, Applications and Impacts on the Environment \& Industrial Processes/ Lerher, T. New York: Nova Publishers, 2013, pp. 51-86.

[14] Heragu, S. S.; Cai, X.; Krishnamurthy, A.; Malmborg, C. J. Analytical models for analysis of automated warehouse material handling systems. // International Journal of Production Research. 49(2011), pp. 6833-6861. https://doi.org/10.1080/00207543.2010.518994

[15] Ekren, B. Y.; Heragu, S. S. Performance comparison of two material handling systems: AVS/RS and CBAS/RS. // International Journal of Production Research. 50(2012), pp. 4061-4074. https://doi.org/10.1080/00207543.2011.588627

[16] Flynn, M. M.; McMullen, P.; Solis, O. Saving energy using flywheels. // IEEE Industry applications magazine. 6, 14(2008), pp. 69-76. https://doi.org/10.1109/MIAS.2008.929351

[17] Wang, Qin; Xiandai, Jiaotong Jishu. Application of Flywheel Energy Storage in Energy Regeneration System of Port Crane. // Modern Transportation Technology. 11, 3(2014), pp. 77-79.

[18] Liu, Haiwei; Mi, Weijian; Zhao, Ning; Feng, Yufei. Modelling and Simulating the Operation of the Harbor Portal Crane. // Journal of Coastal Research, suppl. Special Issue SI.73 (2015), pp. 89-94

https://doi.org/10.2112/SI73-016.1

\section{Authors' addresses}

Boris Jerman, assist. prof. $d r$.

University of Ljubljana,

Faculty of Mech. Engineering, Ljubljana

Aškerčeva cesta 6 ,

1000 Ljubljana, Slovenia

boris.jerman@fs.uni-lj.si

\section{Nenad Zrnić, prof. dr.}

University of Belgrade,

Faculty of Mech. Engineering, Belgrade

Kraljice Marije 16,

11120, Beograd 35, Serbia

nzrnic@mas.bg.ac.rs

Matjaž Jenko, MSc

Riko d.o.o., Ljubljana

Tehnološki park 18/C1,

1000 Ljubljana, Slovenia

matjaz.jenko@riko.si

Tone Lerher, prof. dr.

University of Maribor, Faculty of Logistics, Celje

Mariborska cesta 7 ,

3000 Celje, Slovenia

tone.lerher@um.si 